\title{
Ghrelin against alendronate-induced gastric damage in rats
}

\author{
S Ö Íşeri, G Şener ${ }^{1}, M$ Yüksel $^{3}$, G Contuk $^{2}$, Ş Çetinel ${ }^{2}$, N Gedik $^{4}$ \\ and $\mathbf{B}$ Ç Yeğen
} Department of Physiology, Marmara University School of Medicine, Istanbul, Turkey
${ }^{1}$ School of Pharmacy, Department of Pharmacology, Marmara University School of Medicine, Istanbul, Turkey
${ }^{2}$ Department of Histology and Embryology, Marmara University School of Medicine, Istanbul, Turkey
${ }^{3}$ Vocational School of Health Related Professions, Marmara University School of Medicine, Istanbul, Turkey
${ }^{4}$ Division of Biochemistry, Kasımpasa Military Hospital, Istanbul, Turkey
(Requests for offprints should be addressed to B Ç Yeğen, Department of Physiology, Marmara University School of Medicine, Haydarpaşa, Istanbul 34668,
Turkey; Email: byegen@marmara.edu.tr)

\begin{abstract}
Alendronate sodium, a primary amino bisphosphonate, is widely used in the treatment of various diseases that are associated with bone resorption, such as postmenopausal osteoporosis and Paget's disease of bone. Although the adverse effects of biphosphonates on the gastrointestinal system have been demonstrated in experimental and clinical studies, the exact mechanisms underlying this damage are not clear yet. Ghrelin, a 28 amino acid peptide produced predominantly by the stomach, was shown to exert a potent protective action on the stomach of rats exposed to ethanol or stress.

Our objective was to evaluate the possible antioxidant and anti-inflammatory effects of ghrelin against alendronate-induced gastric damage. Wistar albino rats were administered alendronate $(20 \mathrm{mg} / \mathrm{kg})$ by gavage for 4 days, along with either ghrelin $(10 \mathrm{ng} / \mathrm{kg}$ per day $)$ or saline given i.p. After decapitation, stomach tissues were removed for the determination of malondialdehyde (MDA) and glutathione (GSH) levels, myeloperoxidase
\end{abstract}

(MPO) activity and tissue collagen content, while the extent of tissue damage was analyzed microscopically. Formation of reactive oxygen species was determined by chemiluminesence using a luminol probe in fresh gastric tissues. Serum tumor necrosis factor (TNF- $\alpha$ ) and lactate dehydrogenase levels were assessed in trunk blood.

Oral administration of alendronate-induced significant gastric damage, accompanied by increased MPO activity, collagen content, MDA and luminol levels $(P<0 \cdot 01-$ $P<0 \cdot 001)$, while tissue GSH was decreased $(P<0 \cdot 01)$. On the other hand, ghrelin treatment reversed these alterations $(P<0 \cdot 05-P<0 \cdot 001)$ as well as elevating serum TNF- $\alpha$ levels significantly $(P<0 \cdot 001)$.

The findings of the present study suggest that alendronate induces oxidative gastric damage by a local irritant effect, and ghrelin ameliorates this damage by its possible antioxidant and anti-inflammatory properties.

Journal of Endocrinology (2005) 187, 399-406

\section{Introduction}

The bisphosphonates are a class of compounds known for their ability to prevent osteoclast-mediated bone resorption (Geddes et al. 1994) and recommended for the treatment of various disease conditions with enhanced bone resorption, including postmenopausal osteoporosis, Paget's disease, hypercalcemia of malignancy and osteolytic bone metastases (Fleisch 1997, Meunier et al. 1999). These agents are analogs of pyrophosphate, an endogenous inhibitor of bone mineralization (Rosen \& Kessenich 1996). Alendronate sodium (ALD) is a primary aminobisphosphonate and one of the most commonly used members of this group. However, oral administration of bisphosphonates have been associated with gastrointestinally adverse effects including gastritis, gastric ulcer and erosive esophagitis, and it has been demonstrated that bisphosphonates differ in their potential to damage the gastroesophageal mucosa, ALD having a higher potential for such effects (Blank et al. 1997, Lanza et al. 1998, Graham \& Malaty 1999). It was reported that the rate of acute mucosal injury due to ALD was comparable with that observed with non-steroidal anti-inflammatory drugs (Lowe et al. 2000). Generally, these gastrointestinal sideeffects were attributed to high local concentrations of the drug in patients who did not follow dosing instructions properly, or to their having an underlying esophageal or gastric disease (Lanza et al. 1998, Lowe et al. 2000, Graham 2002). Moreover, two large clinical studies revealed that when standard doses of bisphosphonates were administered in the proper manner in female volunteers without gastrointestinal symptoms or initial endoscopic pathology, 
erosions and ulceration in both the stomach and duodenum developed (Lanza et al. 2000, Thomson et al. 2002).

The exact mechanism underlying ALD-induced gastric damage is not clear yet. Marshall et al. (2000) conducted a randomized controlled trial to investigate the effect of ALD on gastric mucosal prostaglandin (PG) synthesis, but no association was found between the ALD-induced gastric mucosal damage and gastric mucosal $\mathrm{PGE}_{2}$ synthesis. Elliott et al. (1998) studied the effect of ALD in rats and rabbits and observed that the damaging effects of the drug were not attributable to changes in gastric acid secretion, blood flow or PG synthesis; they concluded that the damaging effects of ALD on the stomach were due to a topical irritant effect.

Ghrelin is a novel 28 amino acid peptide discovered in rat and human gastrointestinal tract, particularly gastric mucosa, as an endogenous ligand for growth hormone (GH) secretagogue receptor (GHS-R) (Kojima et al. 1999, Ariyasu et al. 2001). This peptide was also shown to affect gastric motility and gastric secretion (Masuda et al. 2000, Date et al. 2001). It has been demonstrated that feeding, food intake and obesity decrease circulating ghrelin levels in humans and rodents (Toshinai et al. 2001, Tschop et al. 2001). Ghrelin secretion is pulsatile and directly related to feeding behavior (Tolle et al. 2002) and it is upregulated during negative nutritional status, fasting and insulininduced hypoglycemia (Toshiani et al. 2001), suggesting that ghrelin plays an important role in the regulation of feeding behavior, energy balance and obesity. Previous reports have indicated that ghrelin protects against ethanol-induced gastric ulcer (Sibilia et al. 2003) and exerts both specific and selective inhibitory effects on the expression and production of the inflammatory cytokines (Dixit et al. 2004). On the other hand, ghrelin infusions in lipopolysaccharide-challenged mice resulted in a significant attenuation of anorexia and led to inhibition of the proinflammatory cytokines, interleukin (IL)-6, IL-1 $\beta$ and TNF- $\alpha$ (Dixit et al. 2004), which are known to play an important critical role in the development of anorexia-cachexia syndrome (Inui 1999).

On the basis of this background, the present study was designed to elucidate the putative protective effect of ghrelin treatment on ALD-induced damage in the rat gastric mucosa.

\section{Materials and Methods}

\section{Animals}

Adult Wistar albino rats (250-300 g) of both sexes were kept in a light- and temperature-controlled room $(12 \mathrm{~h}$ light: $12 \mathrm{~h}$ darkness, $22 \pm 0 \cdot 5{ }^{\circ} \mathrm{C}$ ) with relative humidity (65-70\%) kept constant. The animals were fed a standard pellet. Experiments were approved by the Marmara
University School of Medicine, Animal Care and Use Committee.

Based on our previous studies (Sener et al. 2004, 2005), ALD was given by gavage $(20 \mathrm{mg} / \mathrm{kg})$ once a day for 4 days following overnight fasting periods. Either ghrelin $(10 \mathrm{ng} / \mathrm{kg}$ per day) or saline was given i.p. immediately after and $6 \mathrm{~h}$ after ALD administration. This antiinflammatory dose of ghrelin was chosen based on our earlier experiments in rats with acute pancreatitis (Kasimay et al. unpublished observations). A control group had no orogastric or i.p. treatments. Each group consisted of six animals. On the 4th day, rats were decapitated $1 \mathrm{~h}$ after the last treatment, and the trunk blood was collected and centrifuged $(4000 \mathrm{~g}, 20 \mathrm{~min})$ for the measurement of serum TNF- $\alpha$ and lactate dehydrogenase (LDH) levels. Serum LDH activity was measured as a marker of systemic tissue injury. The gastric tissue samples were immediately taken and stored at $-70{ }^{\circ} \mathrm{C}$. Formation of reactive oxygen species in tissue samples was monitored by using a chemiluminescence method. Malondialdehyde (MDA, an end product of lipid peroxidation) and glutathione (GSH, a key antioxidant) levels were measured in another set of tissue samples. Tissue-associated myeloperoxidase (MPO) activity, as indirect evidence of neutrophil infiltration, was measured in both tissue samples, while oxidant-induced tissue fibrosis was determined by tissue collagen content.

\section{Biochemical analysis}

Measurement of serum TNF- $\alpha$ and LDH levels TNF- $\alpha$ was evaluated by an RIA-IRMA method. All samples were assayed in duplicate using a commercial kit (Biosource Europe SA, Nivelles, Belgium). The activity of radioactive assays was measured by a gamma counter (LKB Wallac 1270 Rack Gamma Counter; Turku, Finland). TNF- $\alpha$ in the serum samples was expressed as $\mathrm{ng} / \mathrm{ml}$. LDH was determined spectrophotometrically using an automated analyzer (OpeRA, Bayer, USA).

Tissue MPO activity MPO is an enzyme that is found predominantly in the azurophilic granules of polymorphonuclear leukocytes (PMNs) and tissue MPO activity correlates significantly with the number of PMNs determined histochemically in inflamed tissues (Bradley et al. 1982). Thus, tissue-associated MPO activity was utilized as an indication of accumulation of neutrophils. All reagents for MPO assay were obtained from Sigma (St Louis, MO, USA). The tissue samples $(0 \cdot 2-0 \cdot 3 \mathrm{~g})$ were homogenized in 10 volumes of ice-cold potassium phosphate buffer $\left(50 \mathrm{mM} \mathrm{K}_{2} \mathrm{HPO}_{4}\right.$, $\mathrm{pH}$ 6.0) containing hexadecyltrimethylammonium bromide (HETAB; $0.5 \%$ $\mathrm{w} / \mathrm{v})$. The homogenate was centrifuged at $12000 \boldsymbol{g}$ for $10 \mathrm{~min}$ at $4{ }^{\circ} \mathrm{C}$, and the supernatant was discarded. The pellet was then re-homogenized with an equivalent volume of $50 \mathrm{mM} \mathrm{K} \mathrm{K}_{2} \mathrm{HPO}_{4}$ containing $0.5 \%$ (w/v) 
HETAB and $10 \mathrm{mM}$ EDTA (Sigma). MPO activity was assessed by measuring the $\mathrm{H}_{2} \mathrm{O}_{2}$-dependent oxidation of o-dianizidine $2 \mathrm{HCl}$. One unit $(\mathrm{U})$ of enzyme activity was defined as the amount of the MPO present/g tissue weight that caused a change in absorbance of $1.0 / \mathrm{min}$ at $460 \mathrm{~nm}$ and $37^{\circ} \mathrm{C}$ (Bradley et al. 1982).

Tissue GSH and MDA assays Stomach samples were homogenized in ice-cold $150 \mathrm{mM} \mathrm{KCl}$ for determination of MDA and GSH levels. The MDA levels were assayed for products of lipid peroxidation (Beuge \& Aust 1978). Results are expressed as nmol MDA/g tissue. GSH was determined by a spectrophotometric method using Ellman's reagent (Beutler 1975). Results are expressed as $\mu \mathrm{mol} \mathrm{GSH} / \mathrm{g}$ tissue.

Tissue collagen measurement Gastric collagen contents were determined as a marker of oxidant-induced fibrosis. Tissue samples were cut with a razor blade and immediately fixed in $10 \%$ formalin in $0.1 \mathrm{M}$ phosphate buffer $(\mathrm{pH} \mathrm{7.2)}$ in paraffin and sections of $15 \mu \mathrm{m}$ thick were obtained. Collagen content was measured according to a method described by Lopez de Leon \& Rojkind (1985). The method is based on selective binding of the dyes Sirius Red and Fast Green FCF to collagen and non-collagenous components respectively. Both dyes were eluted readily and simultaneously by using $0.1 \mathrm{M}$ $\mathrm{NaOH}$-methanol (1:1). Finally, the absorbances at 540 and $605 \mathrm{~nm}$ were used to determine the amount of collagen and protein respectively.

Chemiluminescence assay To assess the role of reactive oxygen species in ALD-induced gastric damage, luminol chemiluminescence, which measures the formation of hydroxyl radical, $\mathrm{H}_{2} \mathrm{O}_{2}$, hypochloride and peroxynitrite $\left(\mathrm{ONOO}^{-}\right)$, was monitored at room temperature using a Mini Lumat LB 9506 luminometer (EG \& G Berthold, Bad Wildbad, Germany). Luminol (5-amino-2,3dihydro-1,4-phthalazinedione) was obtained from Sigma. Tissue samples were put into a vial and chemiluminescence counts were obtained after the addition of $0.2 \mathrm{mM}$ luminol (Haklar et al. 2002). Counts were obtained at $15 \mathrm{~s}$ intervals for $10 \mathrm{~min}$ and corrected for $\mathrm{mg}$ of tissue sample. Data were expressed as area under the curve of relative light units (rlu).

\section{Histopathological analysis}

Samples were fixed in 10\% formalin solution and following dehydration in a descending series of ethyl alcohol, were cleared in xylene and embedded in paraffin. Paraffin sections of tissues were cut at $6 \mu \mathrm{m}$ on a rotary microtome, mounted on slides, and stained with hematoxylineosin (H\&E) and examined under an Olympus BH-2 photomicroscope.

\section{Statistical analysis}

Statistical analysis was carried out using GraphPad Prism 3.0 (GraphPad Software, San Diego, CA, USA). All data are expressed as means \pm S.E.M. Groups of data were compared by ANOVA followed by Tukey's multiple comparison tests. Values of $P<0.05$ were regarded as significant.

\section{Results}

\section{Serum TNF- $\alpha$ and LDH levels}

In the ALD-administered rats treated with saline, serum TNF- $\alpha$ levels were significantly increased $(23 \cdot 0 \pm 2 \cdot 5 \mathrm{pg} /$ $\mathrm{ml} ; P<0 \cdot 001)$ when compared with the control group $(7.6 \pm 0.9 \mathrm{pg} / \mathrm{ml})$, while ghrelin treatment abolished this elevation $(6 \cdot 4 \pm 0 \cdot 6 \mathrm{pg} / \mathrm{ml} ; P<0 \cdot 001)$ (Fig. 1A). On the other hand, significantly increased serum LDH levels $(2558 \pm 196 \cdot 2 \mathrm{U} / 1 ; P<0 \cdot 001)$ in the ALD plus saline administered rats as compared with the control group $(1543 \pm 126 \cdot 1 \mathrm{U} / \mathrm{l})$ were not reduced by the ghrelin treatment $(2518 \pm 153 \cdot 1 \mathrm{U} / \mathrm{l} ; P<0 \cdot 01)$ (Fig. 1B).

\section{Tissue MDA and GSH levels}

Tissue MDA levels were increased in the ALD-treated group $(14 \cdot 3 \pm 1 \cdot 1 \mathrm{nmol} / \mathrm{g} ; P<0 \cdot 05)$ when compared with the control group $(10 \cdot 3 \pm 1 \cdot 0 \mathrm{nmol} / \mathrm{g})$. Ghrelin treatment reduced the ALD-induced increase in MDA levels $(9 \cdot 7 \pm 0.9 \mathrm{nmol} / \mathrm{g} ; P<0 \cdot 05)$ back to control levels (Fig. 2A). Oral ALD administration significantly reduced gastric GSH levels $(0.9 \pm 0.05 \mu \mathrm{mol} / \mathrm{g} ; P<0 \cdot 05)$ (Fig. 2B), while ghrelin treatment significantly increased the GSH levels $(1 \cdot 4 \pm 0 \cdot 1 \mu \mathrm{mol} / \mathrm{g} ; P<0 \cdot 05)$ back to control levels $(1 \cdot 4 \pm 0.06 \mu \mathrm{mol} / \mathrm{g})$.

\section{Tissue MPO activity}

Oral ALD administration caused a significant increase in gastric neutrophil infiltration, as assessed by elevated MPO activity in the stomach $(26.39 \pm 4.2 \mathrm{U} / \mathrm{g} ; P<0 \cdot 01)$ when compared with the control group $(9 \cdot 9 \pm 1.3 \mathrm{U} / \mathrm{g}$; Fig. 2C). On the other hand, ghrelin treatment prevented the ALD-induced increase in the gastric MPO activity $(15 \cdot 1 \pm 2 \cdot 4 \mathrm{U} / \mathrm{g} ; P<0 \cdot 05)$.

\section{Tissue collagen content}

Gastric collagen content was elevated in the ALDadministered group $(8 \cdot 7 \pm 0 \cdot 1 \mu \mathrm{g} / \mathrm{mg}$ protein; $P<0 \cdot 001)$ when compared with the control group $(6 \cdot 1 \pm 0 \cdot 1 \mu \mathrm{g} / \mathrm{mg}$ protein; Fig. 2D). Ghrelin treatment, on the other hand, reduced the ALD-induced elevation in collagen level (7.2 $\pm 0 \cdot 3 \mu \mathrm{g} / \mathrm{mg}$ protein; $P<0 \cdot 001)$. 
A)

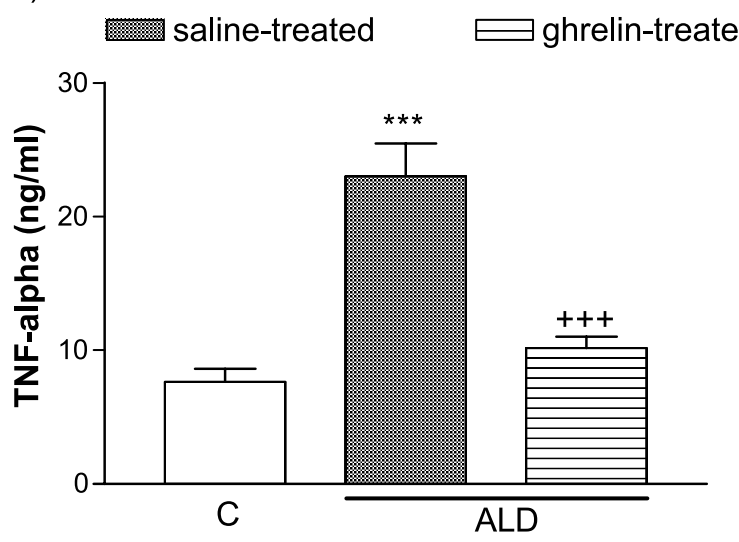

B)

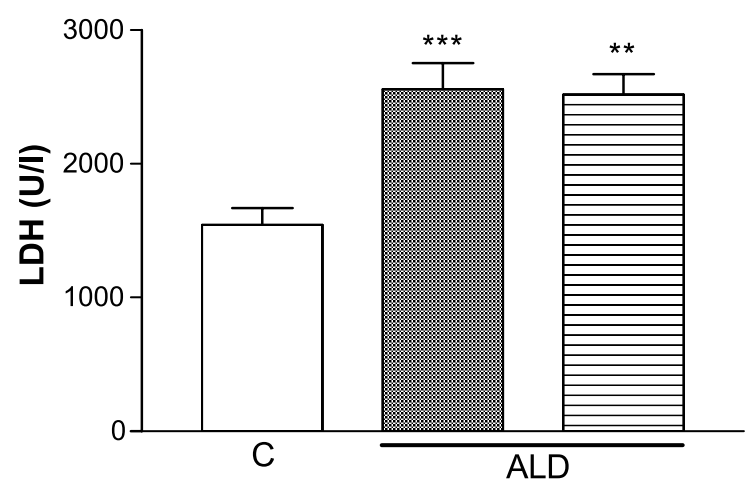

Figure 1 (A) Serum TNF- $\alpha$ and (B) LDH levels of control (' $\mathrm{C}^{\prime}$ ), and alendronate-administered ('ALD', $20 \mathrm{mg} / \mathrm{kg}$ per day) rats, treated with either ghrelin (10 ng/kg per day) or saline for 4 days. In each group $n=6$; mean \pm S.E.M. ${ }^{* *} P<0 \cdot 01$ and ${ }^{* * *} P<0 \cdot 001$ compared with control group; ${ }^{+++} P<0 \cdot 001$ compared with saline-treated ALD group.

\section{Tissue luminol levels}

ALD administration in the saline-treated group significantly increased the gastric luminol level $(40 \cdot 4 \pm 2 \cdot 7 \mathrm{rlu} / \mathrm{mg}$; $P<0 \cdot 01)$ compared with the control group $(22 \cdot 4 \pm$ $3.4 \mathrm{rlu} / \mathrm{mg}$ ), while ghrelin treatment reduced luminol $(28.6 \pm 2 \cdot 1 \mathrm{rlu} / \mathrm{mg} ; P<0 \cdot 05)$ back to the control level (Fig. 2E).

\section{Microscopic evaluation}

The control group had a regular contour of both surface epithelium and fundic glands (Fig. 3A) with regular interglandular spaces. In the saline-treated ALD group, severe congestion of vessels in the connective tissue and prominent dilations among the fundic glands were observed (Fig. 3B). Besides, there was a moderate density of inflammatory cells in the lamina propria. In the ghrelin-treated ALD group, congestion of vessels in the connective tissue was reduced and fewer inflammatory cells were present, while the dilations in the surface and neck epithelia were still present (Fig. 3C).

\section{Discussion}

The results of the present study revealed that ALDinduced gastric injury, as evidenced by the changes in gastric GSH and MDA levels, MPO activity and luminol levels, appears to be an oxidative damage. Ghrelin, which demonstrated anti-inflammatory and antioxidant effects, protected the stomach against ALD-induced oxidative injury. Furthermore, the increase in serum TNF- $\alpha$, which plays a pivotal role in the inflammatory processes, was also reversed by ghrelin treatment.

Bisphosphonates are a choice of effective treatment for osteoporosis but have been associated with gut mucosal injury. The anatomical distribution of both the gastric ulcers and esophageal damage is consistent with the topical irritant effect of bisphosphonates, but its clinical significance is still uncertain (Graham 2002). We have previously investigated the mechanism(s) underlying the gastrointestinal damaging property of chronic treatment with ALD, and suggested that ALD causes gastric damage by a direct effect on the mucosa, resulting in a direct oxidative damage, and also by an indirect oxidative damage through induction of neutrophil infiltration (Sener et al. 2005). It has been previously shown that at $\mathrm{pH}<2$, ALD sodium is converted to its acid form (Peter et al. 1998), which is known to be more irritating than the sodium salt. Since in the present study, ALD was administered orally in fasted rats, it seems likely that the gastric damage is, at least in part, due to the direct irritating effect of the drug in its acid form.

Despite the difficulty in quantifying reactive oxygen metabolites because of their reactive nature and short lives, chemiluminescence as used in the present study, is a simple but a reproducible technique. Luminol-enhanced chemiluminescence data revealed that the toxic metabolites that participate in the ALD-induced gastric damage are mainly $\mathrm{H}_{2} \mathrm{O}_{2}, \mathrm{OH}^{\bullet}$, hypochlorite, peroxynitrite and lipid peroxyl radicals, which can severely disrupt cell membrane function and lead to DNA damage and cell death in the gastrointestinal mucosa (Bagchi et al. 1998, Salvemini et al. 1999). Lipid peroxidation mediated by reactive oxygen metabolites is believed to be an important cause of destruction and damage to gastric mucosa (Bandyopadhyay et al. 2002). In the present study, gastric MDA levels that indicate lipid peroxidation of the membranes were significantly increased after ALD, demonstrating tissue damage. The present results also demonstrated 
A)

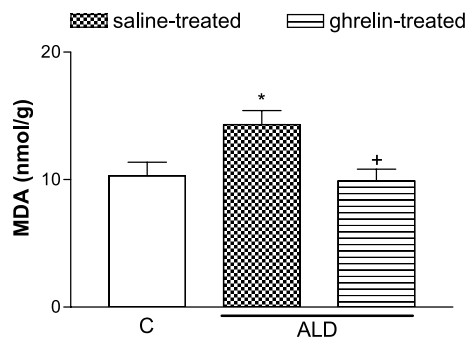

C)

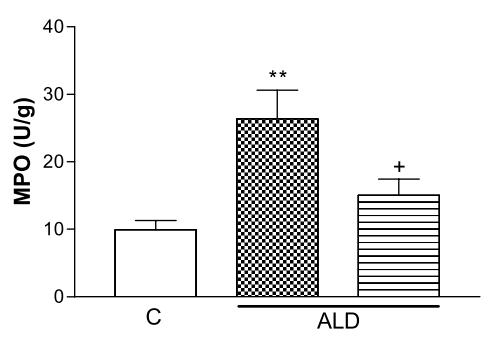

E)

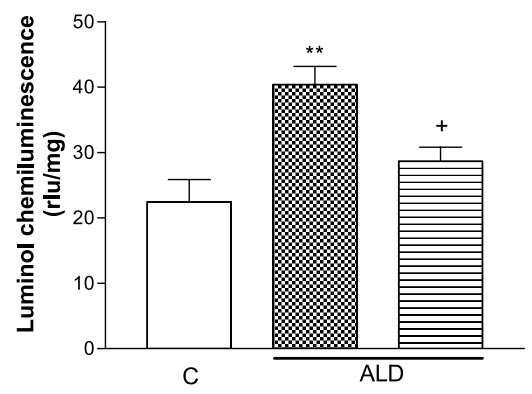

B)

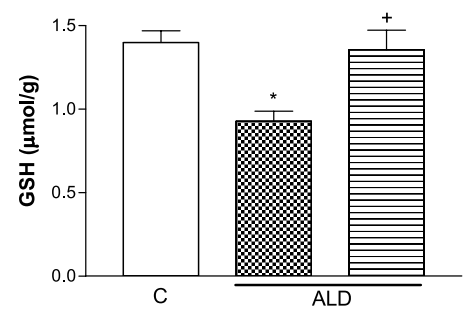

D)

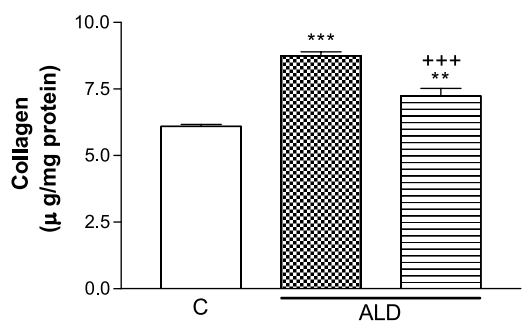

Figure 2 (A) Malondialdehyde (MDA) levels, (B) glutathione (GSH) levels, (C) myeloperoxidase (MPO) activity, (D) collagen levels and (E) luminol levels in the gastric tissues of control $\left({ }^{\prime} C^{\prime}\right)$, and alendronate-administered ('ALD', $20 \mathrm{mg} / \mathrm{kg}$ per day) rats, treated with either ghrelin ( $10 \mathrm{ng} / \mathrm{kg}$ per day) or saline for 4 days. In each group $n=6$; mean \pm S.E.M. ${ }^{*} P<0 \cdot 05,{ }^{* *} P<0 \cdot 01$ and ${ }^{* * *} P<0.001$ compared with control group; ${ }^{+} P<0 \cdot 05$ and ${ }^{+++} P<0 \cdot 001$ compared with saline-treated ALD group. rlu: relative light units.

that ghrelin ameliorates the oxidative injury of the gastric tissue, which appears to involve the inhibition of toxic oxygen metabolite generation, suggesting the presence of an antioxidative function of ghrelin. In accordance with the lipid peroxidation results, the histological findings also support the belief that ghrelin can prevent the gastric damage induced by oral ALD treatment. Moreover, ALD-induced increase in fibrotic activity, as assessed by the collagen contents in the stomach, is reduced by ghrelin treatment, suggesting an additional protective effect on inflammation-induced production and deposition of extracellular matrix components. Similarly, ghrelin was shown to protect against ethanol- (Sibilia et al. 2003) and stress-induced (Brzozowski et al. 2004) gastric ulcers in rats. Since the damaging effects of both ethanol and stress are known to be closely associated with the impairment of mucosal barrier mechanisms, which involves the generation of reactive oxygen species, it is possible that ghrelin, via its antioxidant effects, reinforces the mucosal barrier function, as evidenced in the present study. Furthermore, ghrelin was implicated as having an anti-inflammatory role in Helicobacter pylori infection, where persisting gastric inflammation was associated with lower ghrelin levels (Murray et al. 2003), while the correction of infection has upregulated ghrelin secretion.

There are many studies focusing on the role of oxygen metabolite-mediated lipid peroxidation and neutrophil infiltration in the development of gastric mucosal injury (Ichikawa et al. 2002, Jimenez et al. 2004, Sener et al. 2004). Besides their direct damaging effects on tissues, 
it is well established that oxygen metabolites play a role in the recruitment of neutrophils, preferentially PMNs,
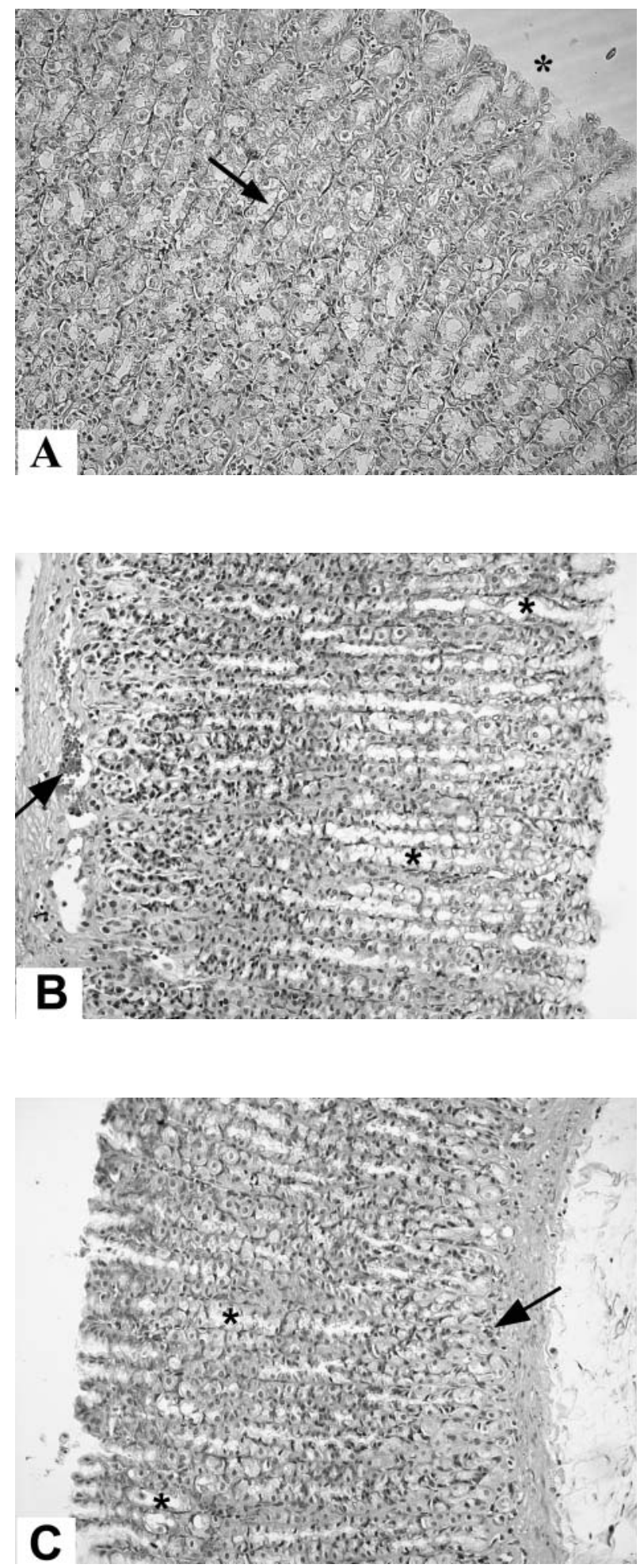

into injured tissues (Zimmerman et al. 1990, Kettle \& Winterbourn 1997). Activated PMNs are also a potential source of oxygen metabolites (Sullivan et al. 2000), initiating the deactivation of antiproteases (Swantek et al. 2000) and activating cytotoxic enzymes including elastase, proteases, lactoferrin and MPO (Kettle \& Winterbourn 1997), thereby generating hypochlorous acid ( $\mathrm{HOCl})$. In the present study, elevated serum TNF- $\alpha$ levels along with increased MPO activity indicate the contribution of PMN infiltration and the impact of pro-inflammatory TNF- $\alpha$ in the oxidative gastric damage. Since ghrelin inhibited the ALD-induced increase in MPO activity and abolished the TNF- $\alpha$ response concomitantly, our results suggest that neutrophil accumulation contributes to ALD-induced gastric injury and the protective effect of ghrelin may be, in part, dependent on its inhibitory effect on tissue neutrophil infiltration and the neutrophilassociated TNF- $\alpha$ response. Previous studies have shown that ghrelin exerts potent anti-inflammatory effects by inhibiting the expression of proinflammatory cytokines such as IL-1 $\beta$, IL-6 and TNF- $\alpha$ (Dixit et al. 2004).

GSH, the main intracellular non-protein sulfhydryl, plays an important role in the maintenance of cellular proteins and lipids in their functional state, and provides major protection by participating in the cellular defense systems against oxidative damage (Ross 1988). GSH and other antioxidants play a critical role in limiting the propagation of oxygen metabolite-mediated lipid peroxidation. It is known that mitochondrial damage may lead to severe GSH depletion, because due to lack of $\gamma$-glutamylcysteine synthetase or GSH synthetase activities mitochondria cannot synthesize GSH, and GSH is transported from the cytosol (Reiter et al. 2000). Thus, gastric GSH depletion in the ALD-treated group of the present study may be attributable to enhanced lipid peroxidation. On the other hand, restoration of tissue GSH levels by ghrelin administration reduced the severity of gastric injury. Thus, it is likely that ghrelin has an important role in the maintenance of gastric GSH, either by increasing the synthesis or by inhibiting the depletion of this crucial antioxidant against the irritant drug-induced lipid peroxidation.

The present data suggest that ghrelin may be of therapeutic use in preventing ALD-induced oxidative gastric injury, by depressing neutrophil infiltration and

Figure 3 (A) Control group. The epithelium shows regular integrity ${ }^{*}$ ) with interepithelial dilations (arrow); (B) Alendronate-treated group. Severe congestion of vessels in the connective tissue of both the subepithelium and lamina propria (arrow); prominent dilations in the surface and neck epithelia $\left(^{*}\right)$ and moderate density of inflammatory cells were observed. (C) Ghrelin-treated group. Congestion of vessels in the connective tissues was reduced (arrow) and fewer inflammatory cells were present; dilations in the surface and neck epithelia were still ongoing $(*)$. $\mathrm{H} \& \mathrm{E} \times 200$. 
inhibiting the release of inflammatory cytokines. In conclusion, the findings of the current study illustrate that exogenously administered ghrelin is capable of ameliorating the gastric side-effect of the anti-osteoporotic drug, ALD. Furthermore, it was suggested that treatment with the endogenous ligand for the GHS-R affects biochemical markers of bone turnover and increases growth velocity in selected short children with or without GH deficiency, while in rodents, GHS treatment increased bone mineral content (Svensson et al. 2001). Although appropriate clinical studies are necessary to test the direct beneficial effect of ghrelin in the treatment of osteoporosis, its protective role in the pharmacotherapy of bone resorption by ALD also merits consideration.

\section{Acknowledgements}

The authors declare that there is no conflict of interest that would prejudice the impartiality of this scientific work.

\section{References}

Ariyasu H, Takaya K, Tagami T, Ogawa Y, Hosoda K, Akamizu T, Suda M, Koh T, Natsui K, Toyooka S, Shirakami G, Usui T, Shimatsu A, Doi K, Hosada H, Kojima M, Kangawa K \& Nakao K 2001 Stomach is a major source of circulating ghrelin, and feeding state determines plasma ghrelin-like immunoreactivity levels in humans. Journal of Clinical Endocrinology and Metabolism 86 4753-4758.

Bagchi D, Carryl OR, Tran MX, Krohn RL, Bagchi DJ, Garg A, Bagchi M, Mitra S \& Stohs SJ 1998 Stress, diet and alcoholinduced oxidative gastrointestinal mucosal injury in rats and protection by bismuth subsalicylate. Journal of Applied Toxicology 18 3-13.

Bandyopadhyay D, Biswas K, Bhattacharyya M, Reiter RJ \& Banerjee RK 2002 Involvement of reactive oxygen species in gastric ulceration: protection by melatonin. Indian Journal of Experimental Biology 40 693-705.

Beuge JA \& Aust SD 1978 Microsomal lipid peroxidation. Methods in Enzymology 52 302-311.

Beutler E 1975 Glutathione in red blood cell metabolism. In $A$ Manual of Biochemical Methods, pp 112-114. Ed. E Beutler. New York: Grune \& Stratton.

Blank MA, Ems BL, Gibson GW, Myers WR, Berman K, Phipps RJ \& Smith PN 1997 Non clinical model for assessing gastric effects of bisphosphonates. Digestive Diseases and Sciences 42 281-288.

Bradley PP, Priebat DA, Christersen RD \& Rothstein G 1982 Measurement of cutaneous inflammation. Estimation of neutrophil content with an enzyme marker. Journal of Investigative Dermatology 78 206-209.

Brzozowski T, Konturek PC, Konturek SJ, Kwiecien S, Drozdowicz D, Bielanski W, Pajdo R, Ptak A, Nikiforuk A, Pawlik WW \& Hahn EG 2004 Exogenous and endogenous ghrelin in gastroprotection against stress-induced gastric damage. Regulatory Peptides 120 39-51.

Date Y, Nakazato M, Murakami N, Kojima M, Kangawa K \& Matsukura S 2001 Ghrelin acts in the central nervous system to stimulate gastric acid secretion. Biochemical and Biophysical Research Communications 280 904-907.

Dixit VD, Schaffer EM, Pyle RS, Collins GD, Sakthivel SK, Palaniappan R, Lillard JW Jr \& Taub DD 2004 Ghrelin inhibits leptin- and activation-induced proinflammatory cytokine expression by human monocytes and T cells. Journal of Clinical Investigation 114 $57-66$.

Elliot SN, McKnight W, Davies NM, MacNaughton WK \& Wallace JL 1998 Alendronate induces gastric injury and delays ulcer healing in rodents. Life Sciences $\mathbf{6 2}$ 77-91.

Fleisch HA 1997 Bisphosphonates: preclinical aspects and use in osteoporosis. Annals of Medicine 29 55-62.

Geddes AD, D'Souza SM, Ebetino FH \& Ibbotson KJ 1994 Bisphosphonates: structure-activity relationships and therapeutic implications. In Bone and Mineral Research, vol 8, pp 265-306. Eds JNM Heersche \& JA Kanis. Amsterdam: Elsevier Science.

Graham DY 2002 What the gastroenterologist should know about the gastrointestinal safety profiles of bisphosphonates. Digestive Diseases and Sciences 47 1665-1678.

Graham DY \& Malaty HM 1999 Alendronate gastric ulcers. Alimentary Pharmacology and Therapeutics 13 515-519.

Haklar U, Yuksel M, Velioglu A, Turkmen M, Haklar G \& Yalcin AS 2002 Oxygen radicals and nitric oxide levels in chondral ar meniscal lesions or both. Clinical Orthopaedics and Related Research 403 135-142.

Ichikawa H, Naito Y, Takagi T, Tomatsuri N, Yoshida N \& Yoshikawa T 2002 A specific peroxisome proliferator-activated receptor-gamma (PPAR-gamma) ligand, pioglitazone, ameliorates gastric mucosal damage induced by ischemia and reperfusion in rats. Redox Report 7 343-346.

Inui A 1999 Cancer anorexia-cachexia syndrome: are neuropeptides the key. Cancer Research 59 4493-4501.

Jimenez MD, Martin MJ, Alarcon de la Lastra C, Bruseghini L, Esteras A, Herrerias JM \& Motilva V 2004 Role of L-arginine in ibuprofen-induced oxidative stress and neutrophil infiltration in gastric mucosa. Free Radical Research 38 903-911.

Kettle AJ \& Winterbourn CC 1997 Myeloperoxidase: a key regulator of neutrophil oxidant production. Redox Report 3 3-15.

Kojima M, Hosoda H, Date Y, Nakazo M, Matsuo H \& Kangawa K 1999 Ghrelin is a growth-hormone-releasing acylated peptide from stomach. Nature 402 656-660.

Lanza F, Rack MF, Simon TJ, Lombardi A, Reyes R \& Suryawanshi S 1998 Effects of alendronate on gastric and duodenal mucosa. American Journal of Gastroenterology 93 753-757.

Lanza FL, Hunt RH, Thomson AB, Provenza JM \& Blank MA 2000 Endoscopic comparison of esophageal and gastroduodenal effects of risedronate and alendronate in postmenopausal women. Gastroenterology 119 631-638.

Lopez De Leon A \& Rojkind M 1985 A simple micromethod for collagen and total protein determination in formalin-fixed paraffinembedded sections. Journal of Histochemistry and Cytochemistry 33 737-743.

Lowe CE, Depew TW, Vanner SJ, Paterson WG \& Meddings JB 2000 Upper gastrointestinal toxicity of alendronate. American Journal of Gastroenterology 95 634-640.

Marshall JK, Rainsford KD, James C \& Hunt RH 2000 A randomized controlled trials to assess alendronate-associated injury of the gastrointestinal tract. Alimentary Pharmacology and Therapeutics 14 1451-1457.

Masuda Y, Tanaka T, Inomata N, Ohnuma N, Tanaka S, Itoh Z, Hosoda H, Kojima M \& Kangawa K 2000 Ghrelin stimulates gastric acid secretion and motility in rats. Biochemical and Biophysical Research Communications 267 905-908.

Meunier PJ, Delmas PD, Eastell R, McClung MR, Papapoulos S, Rizzoli R, Seeman E \& Wasnich RD 1999 Diagnosis and management of osteoporosis in postmenopausal women: clinical guidelines. Clinical Therapeutics 21 1025-1044.

Murray CD, Kamm MA, Bloom SR \& Emmanuel AV 2003 Ghrelin for the gastroenterologist: history and potential. Gastroenterology $\mathbf{1 2 5}$ 1492-1502. 
Peter CP, Handt LK \& Smith SM 1998 Esophageal irritation due to alendronate sodium tablets. Digestive Diseases and Sciences 43 1998-2002.

Reiter RJ, Tan DX, Osuna C \& Gitto E 2000 Actions of melatonin in the reduction of oxidative stress. A review. Journal of Biomedical Sciences 7 444-458.

Rosen CJ \& Kessenich CR 1996 Comparative clinical pharmacology and therapeutic use of bisphosphonates in metabolic bone diseases. Drugs $51537-553$

Ross D 1988 Glutathione, free radicals and chemotherapeutic agents. Pharmacology and Therapeutics 37 231-249.

Salvemini D, Riley DP, Lennon PJ, Wang ZQ, Currie MG, Macarthur H \& Misko TP 1999 Protective effects of a superoxide dismutase mimetic and peroxynitrite decomposition catalysts in endotoxin-induced intestinal damage. British Journal of Pharmacology 127 685-692.

Sener G, Paskaloglu K, Kapucu C, Cetinel S, Contuk G \& Ayanoglu-Dülger G 2004 Octreotide ameliorates alendronateinduced gastric injury. Peptides 25 115-121.

Sener G, Kapucu, Cetinel S, Cikler E \& Ayanoglu-Dülger G 2005 Gastroprotective effect of leukotriene receptor blocker montelukast in alendronate-induced lesions of the rat gastric mucosa. Prostoglandins, Leukotrienes and Essential Fatty Acids 72 1-11.

Sibilia V, Rindi G, Pagani F, Rapetti D, Locatelli V, Torsello A, Campanini N, Deghenghi R \& Netti C 2003 Ghrelin protects against ethanol-induced gastric ulcers in rats: studies on the mechanisms of action. Endocrinology 144 353-359.

Sullivan GW, Sarembock IJ \& Linden J 2000 The role of inflammation in vascular diseases. Journal of Leukocyte Biology 67 591-602.
Svensson J, Lall S, Dickson SL, Bengtsson BA, Romer J, Ahnfelt-Ronne I, Ohlsson C \& Jansson JO 2001 Effects of growth hormone and its secretagogues on bone. Endocrine 14 63-66.

Swantek JL, Tsen MF, Cobb MH \& Thomas JA 2000 IL-1 receptor-associated kinase modulates host responsiveness to endotoxin. Journal of Immunology 164 4301-4306.

Thomson AB, Marshall JK, Hunt RH, Provenza JM, Lanza FL, Royer MG, Li Z, Blank MA \& Risedronate Endoscopy Study Group 200214 day endoscopy study comparing risedronate and alendronate in postmenopausal women stratified by Helicobacter pylori status. Journal of Rheumatology 29 1965-1974.

Tolle V, Bassant MH, Zizzari P, Poindessous-Jazat F, Tomasetto C \& Epelbaum J 2002 Ultradian rhythmicity of ghrelin secretion in relation with $\mathrm{GH}$, feeding behavior, and sleep-wake patterns in rats. Endocrinology 143 1353-1361.

Toshinai K, Mondal MS, Nakazato M, Date Y, Murakami N, Kojima M, Kangawa K \& Matsukura S 2001 Upregulation of ghrelin expression in the stomach upon fasting, insulin-induced hypoglycemia and leptin administration. Biochemical and Biophysical Research Communications 281 1220-1225.

Tschop M, Weyer C, Tataranni PA, Devanarayan V, Ravussin E \& Heiman ML 2001 Circulating ghrelin levels are decreased in human obesity. Diabetes $\mathbf{5 0}$ 707-709.

Zimmerman BJ, Grisham MB \& Granger DN 1990 Role of oxidants in ischemia-reperfusion induced granulocyte infiltration. American Journal of Physiology 258 G185-G190.

Received in final form 11 August 2005 Accepted 9 September 2005 